\title{
Ultracapacitors Utilization for Automotive Applications
}

Z. Pfof, P. Vaculík

This paper describes the basic properties of ultracapacitors and a converter for ultracapacitors with application zero-voltage switching (ZVS). Because of the very high efficiency of the ultracapacitor, the efficiency of the converter for ultracapacitors also has to be high; otherwise, the converter reduces efficiency of the whole drive unit. Further, the paper describes the drive unit concept for the CityEl electric vehicle, with the use of ultracapacitors in cooperation with a fuel cell. This co-operation with ultracapacitors is useful for the supply unit as a fuel cell, which cannot deliver peak power in dynamic conditions while maintaining its nominal efficiency. However, this poses no problems for ultracapacitors.

There is also a description of the basic principles of soft switching using zero-voltage and zero-current switching together with a comparison of the power losses between hard and soft switching.

Keywords: Ultracapacitor, converter for ultracapacitors, soft switching, zero-voltage switching, fuel cell.

\section{Introduction}

The ultracapacitor is a capacitor with large capacitance (up to 5000 Farads) and high efficiency (up to $98 \%$ ). It leads to the idea of using ultracapacitors as an alternative source to batteries, or for extracting higher efficiency from existing power sources, e.g. fuel cells. The ultracapacitor also has other advantages - it is capable of very fast charges and discharges, a millions of cycles without degradation, extremely low internal resistance or ESR, high output power, etc.

Ultracapacitors cannot yet be used as a primary power source in automotive applications. On the other hand, they can be a good choice as a secondary power source that works as an electric power storage system. They are able to deliver peak power for drive demands for acceleration or can be used for storing regenerative braking energy.

BOOSTCAP $®$ ultracapacitors, which are available at our Department of Electronics, are produced by Maxwell Technologies with a capacitance of $3000 \mathrm{~F}$ and a voltage of $2.7 \mathrm{~V}$ DC. Connection in series of these seventeen ultracapacitors creates an ultracapacitor battery pack (Fig. 1) with a capacitance of $176 \mathrm{~F}$ and a voltage of $46 \mathrm{~V}$ DC.

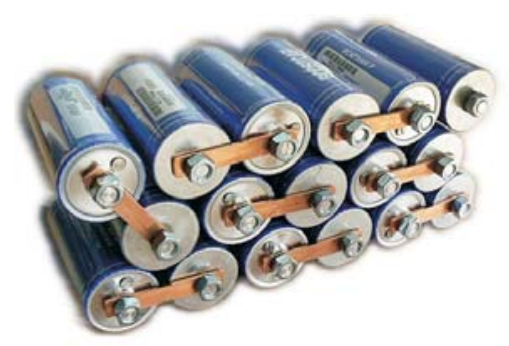

Fig. 1: Ultracapacitor battery pack

A fuel cell or a $\mathrm{LiFePO}_{4}$ battery pack can be used as a primary power source. Fuel cells are still under development, and their parameters will be improved in future. Above all, the price of fuel cells is very high. In addition, it is necessary to maintain the temperature and pressure in the media within operating values. Fuel cells have other disadvantages, but when the main disadvantages are removed, fuel cells will be better than ordinary batteries for supplying electric vehicles.

\section{Soft-switching}

There are two techniques for soft-switching: zero-voltage switching (ZVS) and zero-current switching (ZCS). Resonance on a semiconductor switch from a resonant circuit is used for achieving zero-voltage or zero-current switching conditions. The resonant circuit comprises an inductor $L_{r}$ and a capacitor $C_{r}$. A semiconductor switch with a resonant circuit creates a so-called resonant switch.

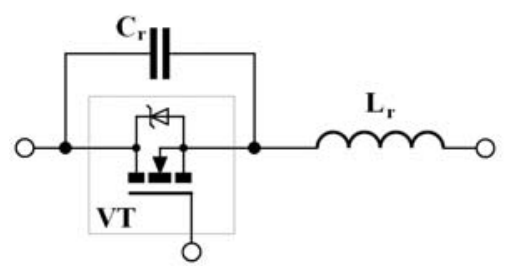

Fig. 2: Schematic diagram of a zero-voltage resonant switch

In order to achieve ZVS capacitor $C_{r}$ is connected in parallel with semiconductor switch $V T$. A zero-voltage resonant switch is shown in Fig. 2. The resonant circuit is used to shape the switch voltage waveform during off time in order to eliminate turn-on loss due to zero voltage on the capacitor or bypass diode conducting. Within the turn-off time, the capacitor creates a slowdown semiconductor switch voltage build-up.

ZVS is suitable for high-frequency operation. The output of converters can be regulated by variable on time or switching frequency control. MOS-FET transistor is the most suitable semiconductor device for ZVS. MOS-FET is an appropriate device for high-frequency applications, but it has two main limitations: the internal output parasitic capacitance and the internal diode. The internal diode has slow dynamic characteristics for turn-off time. For a turn-on transistor with ZVS, the internal diode current decreases slowly, so the internal diode does not need suitable dynamic characteristics. The second limitation also does not apply to ZVS. If the transistor is turned on with zero voltage, the internal parasitic output capacitance does not discharge.

To achieve ZCS, inductor $L_{r}$ is connected in series with semiconductor switch VT. A zero-current resonant switch is 


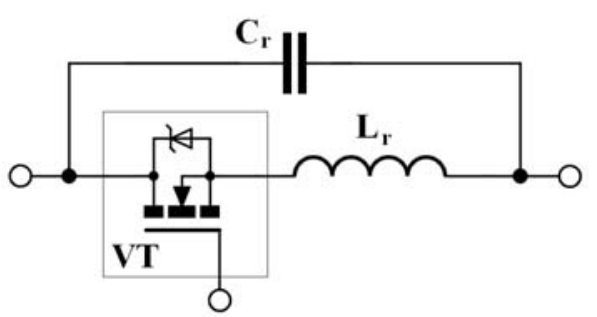

Fig. 3: Schematic diagram of a zero-current resonant switch

shown in Fig. 3. The resonant circuit is used to shape the switch current waveform during conduction time in order to eliminate turn-off loss when zero current flows across the switch and inductor. Within the turn-on time, the inductor creates a slowdown semiconductor switch current build-up, thereby reducing the turn-on loss.

ZCS is suitable for power devices with a large tail current in the turn-off process. The output of converters can be regulated by variable off time control. When selecting a semiconductor device for ZCS, an IGBT transistor is most suitable. The turn-on power loss is lower, because IGBT has considerably lower output capacitance against MOS-FET, but the turn-off power loss is greater owing to the current tail. ZCS eliminates this turn-off power loss, because the turn-off process runs over at zero current. Thus, the power losses are mainly determined by the conduction power losses.

\section{Power losses of hard-switching vs. soft-switching}

Hard-switching is very widely used for power inverters, whereas soft-switching is used only in high frequency applications.
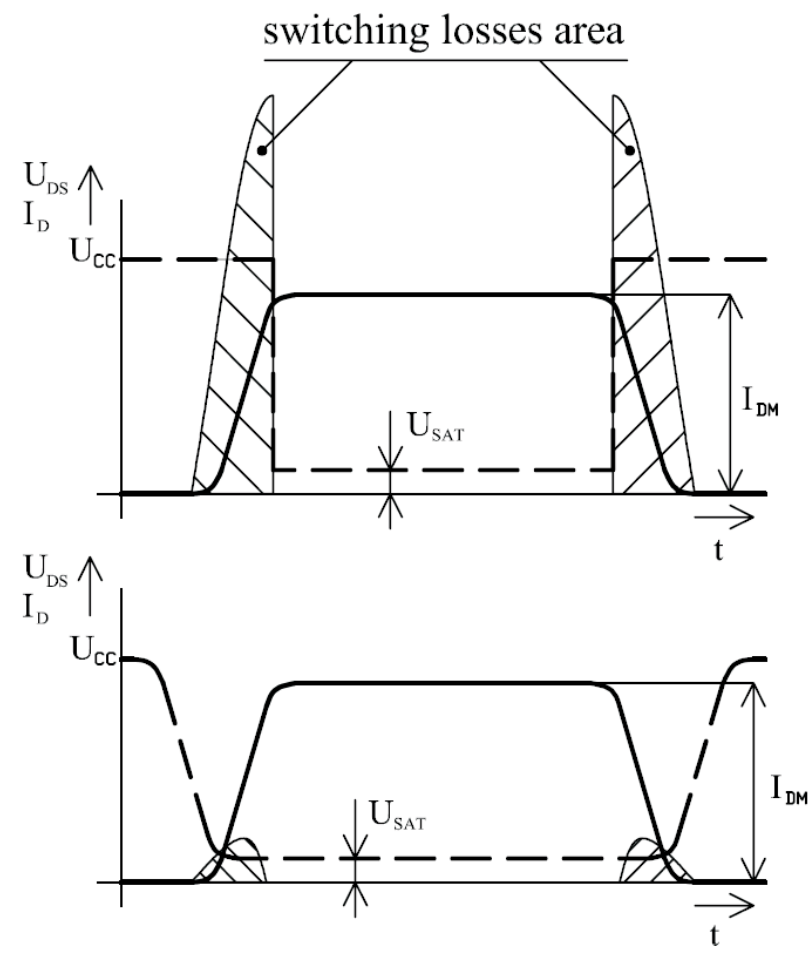

Fig. 4: Switching power losses of hard-switching (top waveform) and soft-switching (bottom waveform)
In an ideal case, the switching losses of soft-switching are zero, because either value of the current or the voltage is zero. But in real cases, the switching losses are not zero, but are distinctly lower than in the case of hard switching. Eq. (1) shows the switching loss ratio between soft-switching and hard-switching.

$$
W_{(\text {soft })}=W_{(\text {hard })} \cdot \frac{U_{\mathrm{SAT}}}{U_{\mathrm{CC}}}
$$

Eq. (1) implies that the switching losses for soft-switching are lower than for hard-switching in the rate of saturation voltage $U_{\mathrm{SAT}}$ and supply voltage $U_{\mathrm{CC}}$. Otherwise, the maximum voltage on the device is saturation voltage for soft-switching. For a better illustration, Fig. 4 shows the waveforms of hard-switching and soft-switching.

\section{A converter for ultracapacitors}

The first concept of a converter for ultracapacitors was designed at the Department of Electronics as a hard-switched converter consisting of a buck converter, ultracapacitors and a two-quadrant boost converter. On the input side, the buck converter charges up the ultracapacitors from the power supply. On the output side, the two-quadrant boost converter increases the output voltage value to $60 \mathrm{~V}$ DC. The ultracapacitor unit measurements show that the use of ultracapacitors decreases the battery loading from the DC motor starting power peaks. Power peaks are required for accelerating a of DC motor with maximum torque. A converter for ultracapacitors is shown in Fig. 5 .

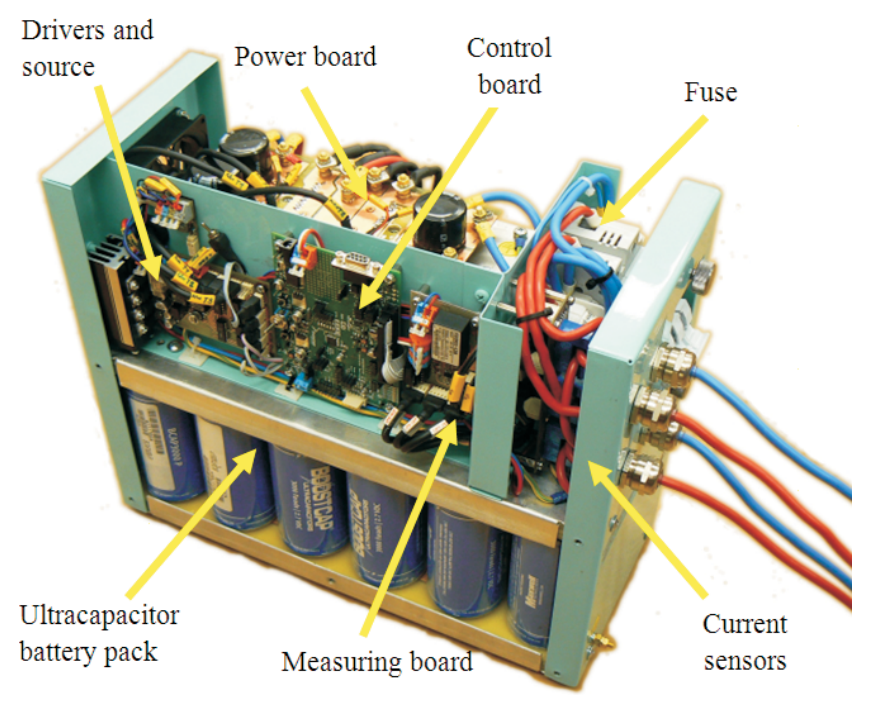

Fig. 5: First concept of a converter for ultracapacitors

As was mentioned above, ultracapacitors are highly efficient (up to $98 \%$ ). Therefore, the converter for ultracapacitors also has to have high efficiency. Otherwise, the converter will reduce the efficiency of the whole drive unit. This can be achieved by soft-switching. Zero-voltage switching is a suitable soft-switching technique for a converter for ultracapacitors. ZVS also provides an effective solution for suppressing converter's EMI while preserving high switching frequency. 


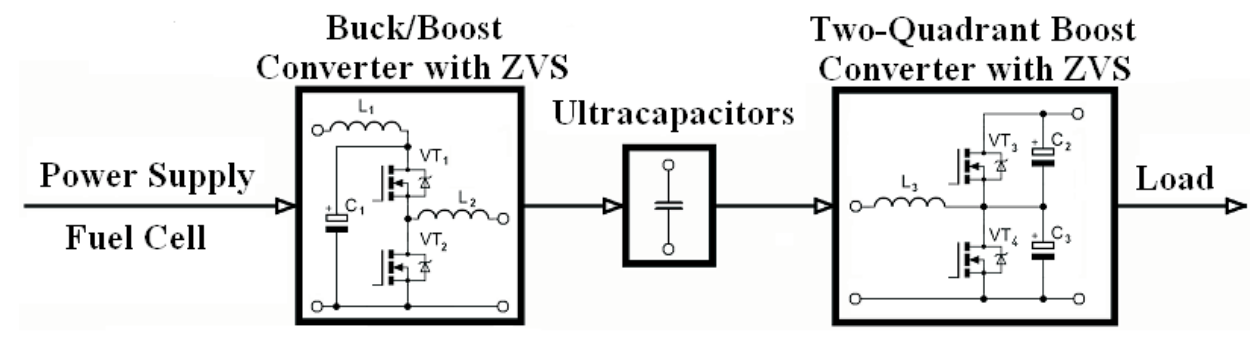

Fig. 6: Block diagram of a converter for ultracapacitors with ZVS

The converter configuration is shown in Fig. 6. The buck/boost converter is on the input side. This input converter can work in two modes: buck or boost mode. When the ultracapacitors are charging up from the power supply created by the fuel cell, the converter works as a buck converter. For a buck converter, we use only top transistor $V T_{1}$, and via its duty cycle, we can control the charge rate of the ultracapacitors and the value of the current that flows directly to the load. The maximum voltage value of the ultracapacitors can be the voltage value of the power supply. Therefore, the input converter can work as a boost converter. Both transistors $V T_{1}, V T_{2}$ are used for the boost converter, and via their duty cycle, we can raise the voltage value of the ultracapacitors that can be increased to maximal voltage value of ultracapacitor battery pack.

The two-quadrant boost converter is on the output side. This converter increases the output voltage to the desired output voltage value, which is the nominal voltage of the electric motor. The output converter can work in two quadrants. It can supply power to the load, or it can regenerate power from the load back to the ultracapacitors. This converter utilizes both transistors to preserve the resonance. Only a transistor duty cycle designates the direction of the power flow.

\section{Simulation results}

In this section, we will present the simulation results for each converter. The simulation was performed in OrCAD 16.0. All simulation results show current and voltage on the resonant switch and the total power loss on semiconductor switch.

Fig. 7 shows the simulation result for the input buck/boost converter in boost mode. In buck mode, the bottom transistor $V T_{2}$ is closed and the charge rate of the ultracapacitors is controlled via duty cycle of top transistor $V T_{1}$. This mode is not as interesting as the boost mode. Therefore, the simulation results are not shown. In boost mode, the top transistor $V T_{1}$ must be open for the whole period. Then the bottom transistor $V T_{2}$ is switched to achieve a boost effect but also to achieve resonance on the resonant switch. The inductor current $I_{L 1}$ rises, when transistor $V T_{2}$ is open. The current that flows through the transistor $V T_{2}$ produces a power loss on this transistor. Fig. 7 shows that the turn-on power loss is almost zero, and the conduction power loss rises gradually.

Fig. 8 and Fig. 9 show the simulation result for the output two-quadrant boost converter. Fig. 8 is for the supply mode, whereas Fig. 9 is for the regeneration mode, which means

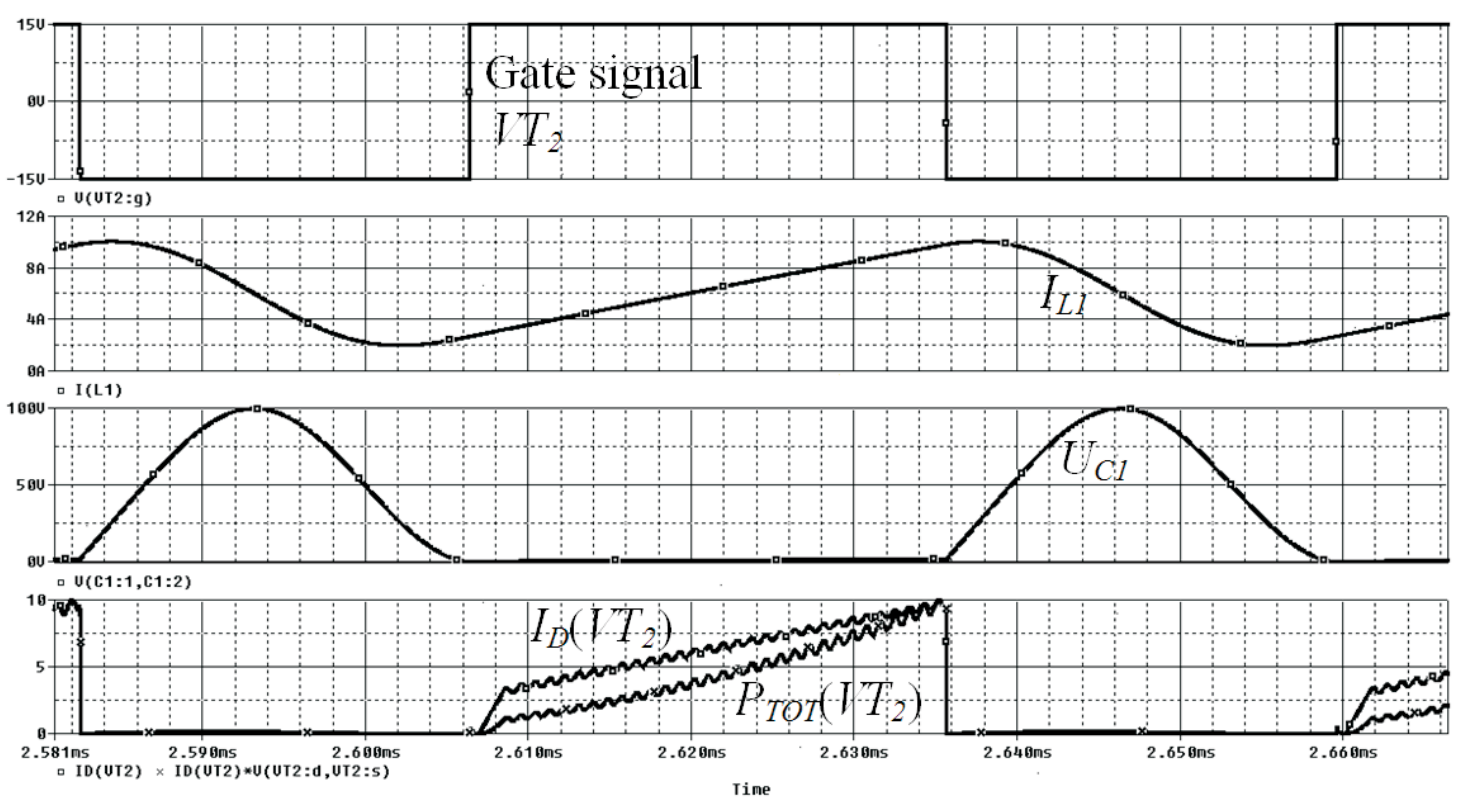

Fig. 7: Simulation results for input buck/boost converter with ZVS; boost mode 


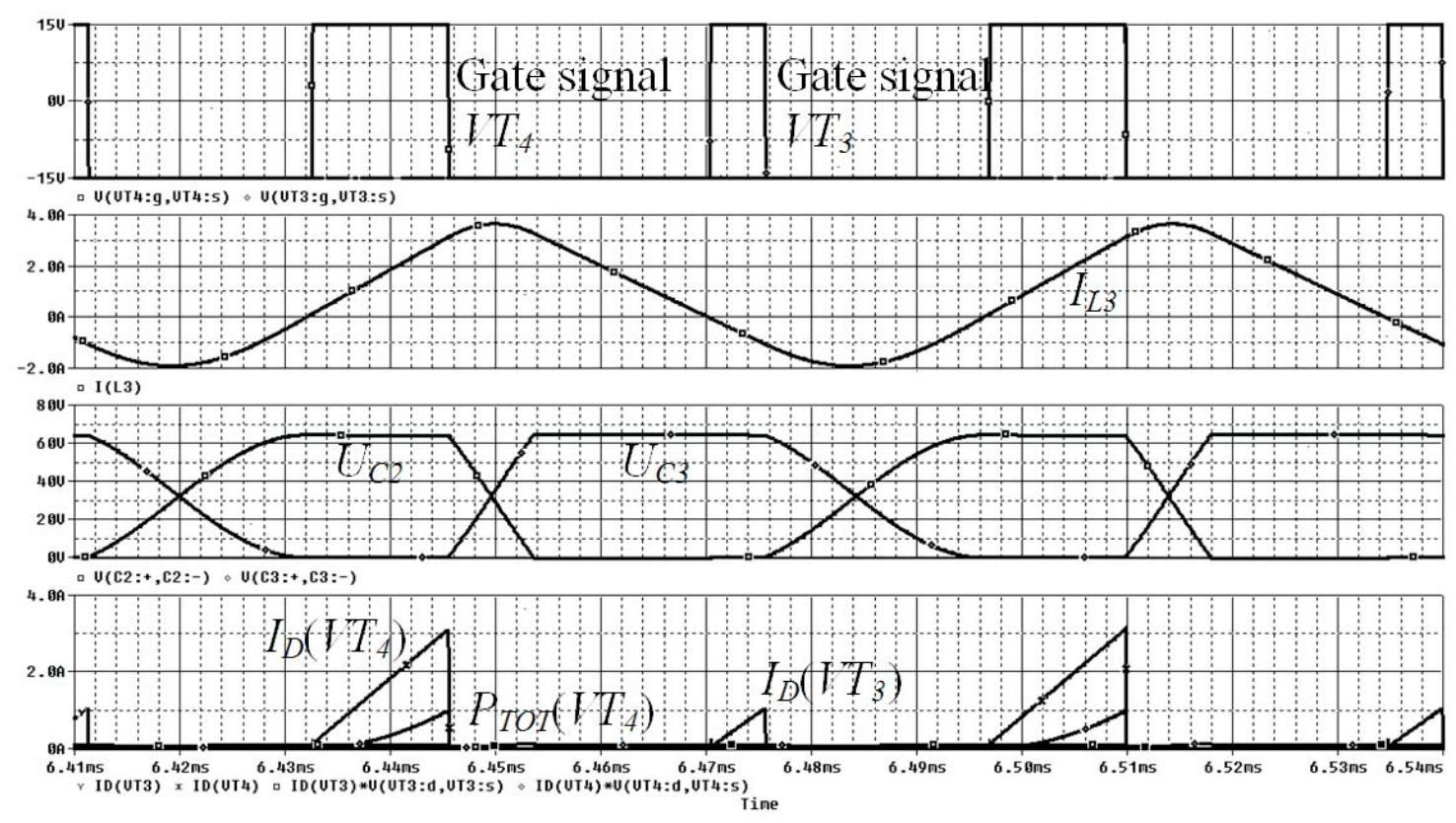

Fig. 8: Simulation results for output two-quadrant boost converter with ZVS; supply mode

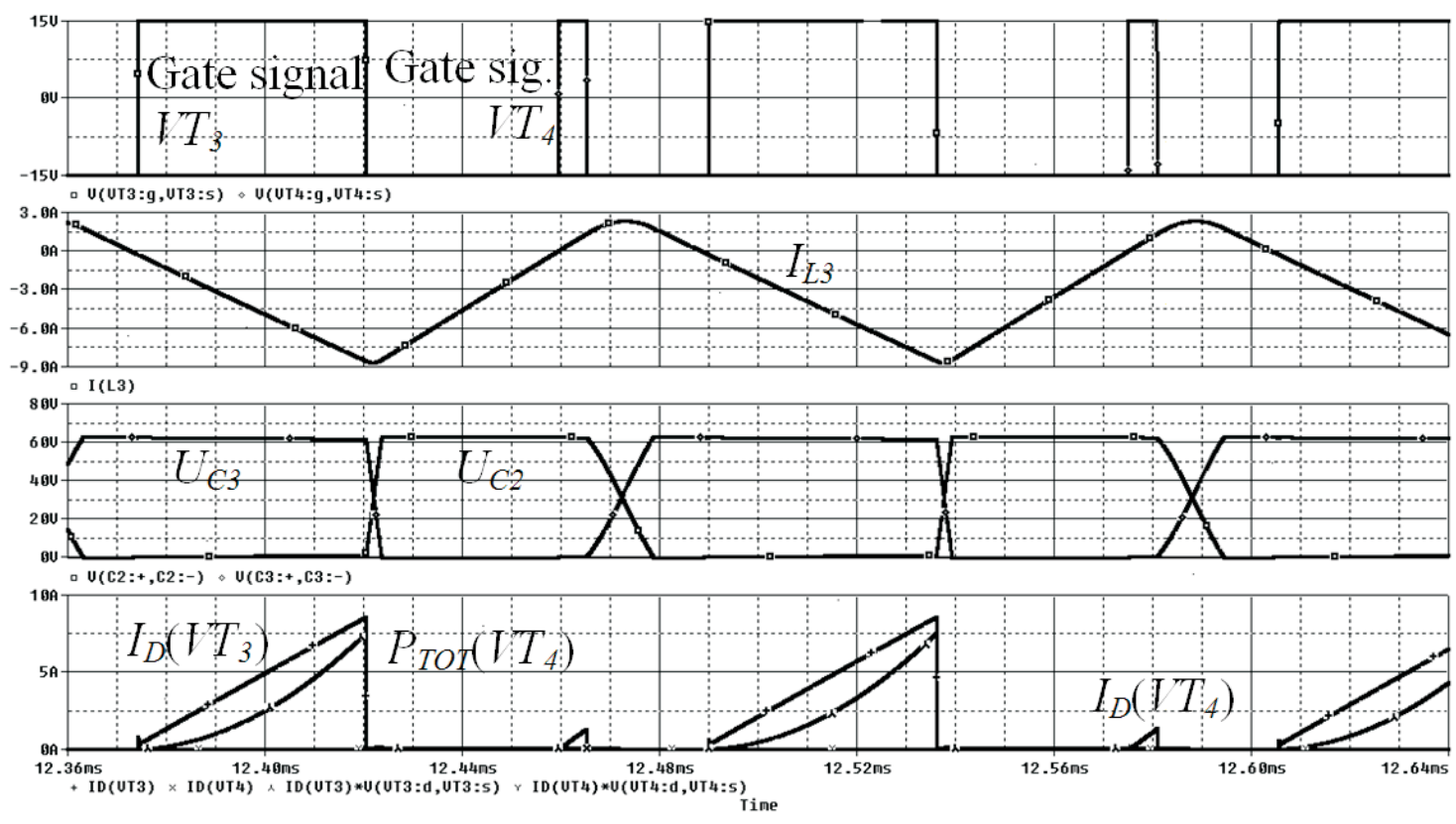

Fig. 9: Simulation results for output two-quadrant boost converter with ZVS; regeneration mode

that the power flows from the load back to the ultracapacitors. In both modes, transistors $V T_{3}$ and $V T_{4}$ are switched for preservation resonance. To generate power to the load the duty cycle of transistor $V T_{4}$ must be greater than the duty cycle of transistor $V T_{3}$, whereas for regenerating power back to the ultracapacitors it is vice versa. Again Fig. 8 and Fig. 9 show that the turn-on power loss is almost zero and the conduction power loss rises gradually.

\section{Concept of the drive unit}

Our Department of Electronics is developing a drive unit for the CityEl electric vehicle, which is a small one-seat city vehicle. At present, the CityEl has a drive unit with a DC motor supplied from a traction battery over a hard-switched converter for the ultracapacitor. Fig. 10 shows a new concept that will be supplies from fuel cell (primary power source) and ultracapacitors (secondary power source), which will deliver peak power to a synchronous motor with a permanent magnet or will store the energy from regenerative braking. The drive unit will comprise a three-phase inverter for controlling the synchronous motor by DTC.

Our concept of a drive unit for the CityEl electric vehicle will have a Nexa fuel cell with output power of $1.1 \mathrm{~kW}$ and output voltage of $25 \mathrm{~V}$ DC. Two fuel cells can deliver output power of $2.2 \mathrm{~kW}$. That will be sufficient output power for the weight (above $280 \mathrm{~kg}$ ) of the CityEl vehicle. 


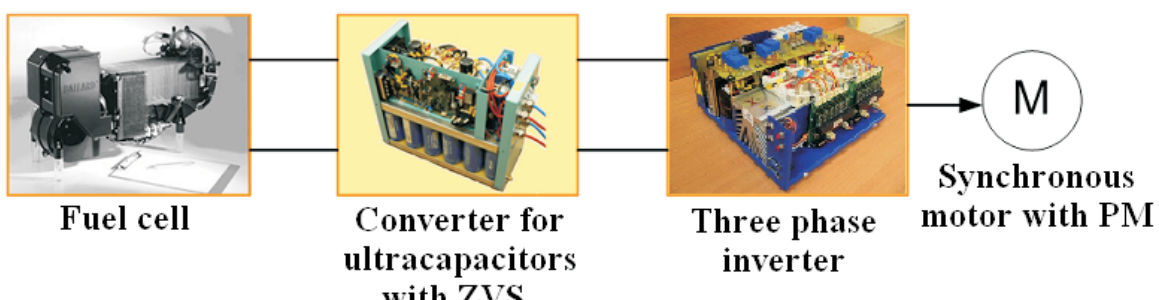

Fig. 10: Concept of the drive unit for the CityEl electric vehicle

The converter for ultracapacitors has another purpose in the drive unit: to increase the voltage value from the fuel cell for the synchronous motor. The motor requires a voltage value from $80 \mathrm{~V}$ to $125 \mathrm{~V}$ AC.

\section{Acknowledgments}

The research described in this paper was supervised by Prof. Ing. Petr Chlebiš, CSc., Department of Electronics, VŠB-Technical University of Ostrava and supported by GAČR project 102/08/0775: New Structures and Control Algorithms of Mobile Hybrid Systems.

\section{References}

[1] Chlebiš, P.: Polovodičové měniče s měkkým spináním. (monograph in Czech), Ostrava: Technical University of Ostrava, 2004, ISBN 80-248-0643-6.

[2] Dudrik, J.: Výkonové vysokofrekvenčné meniče s mäkkým spínanim. Košice: Elfa, 2007, ISBN 978-80-8086-055-4.
[3] Rashid, M. H.: Power Electronics Handbook. California USA: Academic Press, 2001, ISBN 0-12-571650-2.

[4] Rech, P.: Měnič superkapacitoru. Diploma work. VŠB-Technical University of Ostrava, 2007.

Zdeněk Pfof

e-mail: zdenek.pfof@vsb.cz

Petr Vaculík

e-mail: petr.vaculik@vsb.cz

Department of Electronics

VŠB-Technical University of Ostrava

FEECS

17. listopadu 15

70833 Ostrava-Poruba, Czech Republic 